Reports contains 24 papers published by members of the staff of the Brompton Hospital and the London Chest Hospital. The scope is very wide and reflects the trend of interest in different chest diseases. Lung cancer and pulmonary tuberculosis form the core of the volume and there are three papers on cardiac subjects including Sir Russell Brock's ' Technique of Mitral Valvotomy.' Chronic bronchitis, so neglected a disease in the past, is now receiving very full attention and there are three articles on certain aspects of this condition. The 'Reports' maintains the high standard of its predecessor and is recommended to all interested in chest disease.

L.L.B.

\section{CANADIAN JOURNAL OF SURGERY JOURNAL CANADIEN DE CHIRURGIE}

For some years the surgeons of Canada have felt the need for a national journal in which they could publish their own original work. Last year the leading surgical groups in Canada met and requested the Canadian Medical Association to undertake the publishing of a quarterly Canadian Fournal of Surgery. The Association gladly agreed to cooperate in this, and we are happy to announce that the first issue of the Canadian Fournal of Surgery appeared on October I, 1957. The Editorial Board consists of the professors of surgery from the 12 Canadian medical schools, with Dr. R. M. Janes of Toronto, President of the Royal College of Physicians and Surgeons of Canada, as chairman of the Board. Publication is under the general supervision of the Editor of the Canadian Medical Association Fournal.

Enquiries about the Journal should be addressed to Canadian Fournal of Surgery, C.M.A. House, 150 St. George Street, Toronto 5, Ontario.

\section{THE CLINICAL EXAMINATION OF PATIENTS WITH ORGANIC CEREBRAL DISEASE}

By R. Klein, M.D., and W. Mayer-Grass, M.D., F.R.C.P. Pp. xiii +96 . London: Cassell \& Co. Ltd. I957. I5s.

In recent years there has been a considerable advance in the understanding of the disorders of the higher cerebral functions. It cannot be denied that the clinical examination designed to elicit such disorders may be a matter of considerable difficulty, as they are normally multiple and manifest against a background of a varying degree of dementia. A patient who is unable to speak as the result of a cortical lesion will show obvious evidence of a specific defect in cerebral integration, but other equally specific defects, such as disturbances connected with the body scheme, may easily be missed unless they are carefully sought for by special tests. It is the object of this book to present the various ways in which these disordered functions can be examined and analysed. A great deal of the information on this subject has not previously been presented in the form of a textbook and has only appeared in the original articles. It is, therefore, useful to be able to refer to a systematic presentation of these tests and the book can definitely be recommended to both neurologists and psychiatrists interested in the disorders of behaviour that may result from organic cerebral disease.

$$
\text { N.S.G. }
$$

\section{FRACTURES AND RELATED INJURIES}

By J. Grant Bonnin, M.B., B.S., F.R.C.S. Pp. $x+710$, with 775 illustrations. London: William Heinemann Ltd. 1957. 84s.

- The author's aim in writing this book has been to produce a 'practical manual of immediate traumatic surgery and post-traumatic after-care for the postgraduate surgeon and a reference book for the undergraduate.' The volume is divided into two parts: the first, smaller, part covers fractures in general and the second part deals with fractures of individual bones. Sections on chemotherapy and on fractures of the skull and of the face and jaw are contributed by Dr. Allan Gray, Mr. T. G. I. James and Mr. J. N. Barron.

Because of the author's dual aim, a certain unevenness is noticeable throughout the book, a good deal of information useful to the postgraduate surgeon being mixed up with material more suitable for inclusion in a student's textbook. This admixture of elementary material has led to restriction of the space allocated to matters of importance to the practising surgeon. For instance, injuries of nerves are dealt with in two pages, no mention being made of the very important distinction between degenerative and non-degenerative lesions. On the other hand, twice as much space is allocated to a consideration of varieties of fracture, an aspect of the subject with which the postgraduate surgeon could reasonably be expected to be familiar.

The author's statement that 'with succeeding years the principles of treatment of fractures have altered very little' is one that will be generally accepted. It might, however, be expected that in a modern textbook of this nature the reader could be told more about the relative importance of these principles in any one fracture. It might, perhaps, have been better had each section on individual fractures contained rather less about symptoms and signs and rather more about the aims of treatment and about the result likely to be obtained.

Some of the methods of treatment advocated by Mr. Grant Bonnin are open to criticism. For instance, in dealing with the operative treatment of the fracture of the femoral neck he advises that after impaction of the fracture the nail should be driven home. Many men take the view that this last proceeding will produce only one effect-disimpaction 
of the fracture. Again, the Judet arthroplasty, either with a metallic or a plastic prosthesis, is no longer one that commends itself to many surgeons.

The style of writing is uneven, passages in narrative form being occasionally interrupted by verbless sentences. The author's instructions for passing examinations are unlikely to be viewed with favour by those responsible for medical education in this country, while his time-table for a rehabilitation centre, allowing 'free time' from I 900 hours to I 900 hours, is likely to meet with a rather mixed reception from those being rehabilitated.

The idea of the book is a good one, much of the information containec' in it is useful, many references are given (though Holdsworth's work on paraplegia is not mentioned) and the standard of production is excellent. A considerable reappraisal will, however, be needed if it is to fulfil its author's expressed aims.

\section{THE PRINCIPLES AND PRACTICE OF DIATHERMY}

By B. O. ScotT, M.R.C.S., L.R.C.P., D.Phys.Med. Pp. vii +193 , with 146 illustrations. London: William Heinemann Ltd. 1957. 25s.

This book is intended for the physical medicine specialist and physiotherapist and is therefore a technical work. However, the style in which it is written is most readable and the more advanced theoretical considerations are separated from the rest of the text. There are numerous diagrams and illustrations and a useful bibliography follows each chapter.

The author has himself carried out original experimental work and writes with the authority of considerable experience of his subject.

\section{EVERYDAY PAEDIATRICS}

By B. Gans, M.D., M.R.C.P., and L. I. Norian, M.B., B.S. Pp. 216 . London: Faber and Faber. I957. I 2s. $6 \mathrm{~d}$.

There is a lot of common sense and useful information in this little book. The part by Dr. Gans, however, gives the impression that he has heard of and applied many of the new attitudes to disease in childhood without really understanding their basic reasons. For example, it is strange to see that the same doctor who calls constipation 'an AngloSaxon neurosis' advises the use of amphetamine sulphate in the treatment of enuresis! Even writing on physical illness Dr. Gans makes some rash statements: 'The practitioner is unlikely to miss a case of intussusception'; the last child your reviewer saw with an intussusception had been a puzzle to an excellent doctor for five days.

The brief section on the child and the community, by Dr. Norman, giving details of the child welfare service, is useful.

Your reviewer is sure that both the authors of this book are good at the practical task of helpinge children and their parents, but their own personal ways can appear misleading in point.

\section{THE CLOSED TREATMENT OF COMMON}

By John Charnley, B.Sc., M.B., F.R.C.S. Secondo edition. Pp. xii +260 , with 199 illustrations. Edinburgh: E. \& S. Livingstone Ltd. 1957. 50s.

Seven years ago Mr. Charnley published the first $\stackrel{\Phi}{\circ}$ edition of this book, written primarily for the resident casualty surgeon. Fearing that it had been ${ }^{\infty}$ mistaken for an elementary students' manual, he $\overrightarrow{0}$ has now rewritten and revised it 'at postgraduatelevel.' It is perhaps a sign of the times that he has $\vec{\omega}$ felt the need to introduce much material defending $\%$ his advocacy of conservative treatment. Thus ao provocative new first chapter is devoted to the main 3 . features of bone repair and includes many original $\omega$ observations and theories relating to this and the role of operative intervention.

The following chapters are only slightly altered $\stackrel{\infty}{-}$ from the first edition and comprise the bulk and the best of the monograph. An excellent practical and $\frac{1}{\sigma}$ theoretical account is given of the closed treatmento of common fractures with particular emphasis of the primary reduction and immobilization.

Some criticisms are possible. The unwary readêें may gain the impression that all finger fractures are를 treated in plaster, for the chapter with this heading is concerned entirely with the author's method of ${ }^{-}$ treating unstable fractures of the proximal phe $\overrightarrow{\mathbb{P}}$ anges. There is a rather light-hearted dismissal $8 \mathrm{f}$ finger stiffness due to fixation on the grounds that will always recover in time. Perhaps it would haveo been better avoided in the first place by a shorter period of immobilization.

It is regrettable that skin traction is so firmlyo condemned. With a little skill and care it is a safe $\stackrel{\mathbb{Q}}{\circ}$ and effective technique.

The index is poor.

The additions to the book have not increased its usefulness to the casualty officer. In fact, by the insertion of much which is, although thought provoking, unproven or debatable, the text has a을 generally lowered standard of reliability. Nor is it $\underline{3}$. comprehensive: fractures of the clavicle and scaphoid, for example, are not described.

Nevertheless, this is a very valuable book to $\delta$ study and possess. It provides pleasant, stimulating, $₹$ and in places absorbing, reading for all those 0 interested practically and theoretically in what is, after all, the most important way of treating fractures.

A.J.H.

THE FOREQUARTER AMPUTATION

By H. F. Moseley, M.A., D.M., M.Ch., F.R.C.S., F.A.C.S. Pp. viii +79 , with 25 illustrations andoo I I plates in colour. Edinburgh: E. \& S. Livingstone Ltd. 1957. $42 \mathrm{~s}$. 